\title{
Becoming a Fraternal Organization: Insights from the Encyclical Fratelli Tutti
}

\author{
Ricardo Zózimo ${ }^{1}$ (1) $\cdot$ Miguel Pina e Cunha ${ }^{1} \cdot$ Arménio Rego $o^{2,3}$
}

Received: 4 August 2021 / Accepted: 24 January 2022 / Published online: 28 February 2022

(c) The Author(s), under exclusive licence to Springer Nature B.V. 2022

\begin{abstract}
We uncover fundamental dimensions of the process through which organizations embed the practice of fraternity through embarking on an organizational journey in the direction of the common good. Building on the latest encyclical of Pope Francis, Fratelli Tutti, about fraternal and social friendship, we offer insight into the understanding of what it means to become a fraternal organization and reflect on the key ethical and paradoxical challenges for organizations aiming at collectively contributing to the common good. We add to previous work by characterizing this journey as a process involving unique ethical challenges that emerge from the paradoxes associated with this process and how this might change the nature of the relationships between organizations and others within the organizational landscape.
\end{abstract}

Keywords Fratelli Tutti $\cdot$ Fraternity $\cdot$ Ethics $\cdot$ Stakeholders $\cdot$ Paradox

\section{Introduction}

"Business activity is essentially 'a noble vocation, directed to producing wealth and improving our world' (Pope Francis, 2015, § 129) (...) Business abilities, which are a gift from God, should always be clearly directed to the development of others and to eliminating poverty, especially through the creation of diversified work opportunities."

Pope Francis (2020a, § 123).

In his recent encyclical Fratelli Tutti, Pope Francis (2020a) stresses the idea of fraternity to deal with the complex challenges of present time. Although the encyclical is written

Ricardo Zózimo

ricardo.zozimo@novasbe.pt

Miguel Pina e Cunha

miguel.cunha@novasbe.pt

Arménio Rego

arego@ucp.pt

Universidade Nova de Lisboa, Lisbon, Portugal

2 Católica Porto Business School, Universidade Católica Portuguesa, Porto, Portugal

3 Business Research Unit, Instituto Universitário de Lisboa (ISCTE-IUL), Lisbon, Portugal primarily as a means for reflection to "all people of good will” (Pope Francis, 2020a, §6), irrespective of their credo, we consider that the communal descriptions offered when discussing fraternity also resonate with organizational life and challenge both scholars and practitioners to reflect upon new ways by which organizations may pursue the common good. Indeed, both scholars and practitioners have defended that organizations must be rebuilt as communities (Cunha et al., 2014; Mintzberg 2009; Pfeffer 2015) that are purposeful (Hollensbe et al., 2014), and increasingly expected to work toward the common good (Jung \& Kim, 2016; Sasaki et al., 2019; van Marrewijk 2004). Research, however, has not explored how organizations may be fraternal in interacting with stakeholders in the pursuit of the common good. Considering the observations of Pope Francis, and the differences among the interests, values, and aspirations of various stakeholders, we explore what being a fraternal organization means and the ethical challenges and paradoxical tensions emerging from a journey toward a more fraternal world in which organizations are an intrinsic part of "a community that supports and helps us, in which we can help one another to keep looking ahead" (Pope Francis, 2020a, §8).

Drawing inspiration from Pope Francis, we define "fraternal organization" as one whose sense of place, belonging, and responsibility toward the human community living in our "common home" $(2015, \S 67)$ creates possibilities of supporting others for the sake of the common good. We 
visualize a fraternal organization as one that interacts with its stakeholders under the premise of a "shared destination" that invites designing and implementing "better ways of living together on this earth" (Pope Francis, 2020b, p. SR3). A fraternal organization seeks to summon all stakeholders to participate in the process of pursuing the common good. From this perspective, fraternal organizations include all stakeholders that the organization represents as working to address similar challenges and that may participate in the process of pursuing the common good (Retolaza et al., 2019; Simpson et al., 2015). In that sense, a fraternal organization treats its stakeholders as neighbors, i.e., individuals and collectives with a shared destination in the "common home" (Pope Francis, 2015, §67). At the core of the concept of fraternal organization is the notion that regardless of the differences between stakeholders and the challenges and difficulties that addressing them entails, a shared destination and purpose must prevail over those differences, and the organization has the moral duty to care for that destination and purpose.

Despite its importance, the notion of fraternal (rather than instrumental) relationship of organizations with stakeholders is still underdeveloped regarding theory. As a consequence, scholars are less able to help organizations adopt a fraternal approach, an important endeavor amidst the recent worldwide pandemic, poverty, and other dysfunctional effects (at the health, social, political, and economic levels) of the growing inequality in the world (Stockhammer, 2015). It is worth being emphasized here that while Pope Francis has been criticized for being more "impulsive than cerebral" and "[sounding] ultra-radical at times" (The Economist, 2014), his warning that "this economy kills" (see Tornielli $\&$ Galeazzi, 2015) has resonance in research demonstrating the effects of current economic practices (see, e.g., Payne, 2018; Pickett \& Wilkinson, 2015; Wilkinson \& Pickett, 2009, 2017). ${ }^{1}$

Overall, we depart from the assumption that Catholic Social Teaching ${ }^{2}$ is a source of wisdom helping organizations to become more virtuous (Cremers, 2017; Guitián, 2021) in contributing to a more effective pursuit of sustainable development (Ferraro et al., 2015; George et al., 2016).

\footnotetext{
1 Indeed, The Economist (2014) did Pope Francis justice by acknowledging that he "does not pretend either to be an academic philosopher, political scientist, or economist; he is a more intuitive figure, and his intuitions are often sound (...) Francis may not be offering all the right answers, or getting the diagnosis exactly right, but he is asking the right questions. Like a little boy who observes the emperor's nakedness".

2 The "Compendium of the social doctrine of the church" can be found at https://www.vatican.va/roman_curia/pontifical_councils/ justpeace/documents/rc_pc_justpeace_doc_20060526_compendiodott-soc_en.html (accessed on 19 January 2022).
}

Thus, we add conceptual texture to current understanding of organizations and the possibilities of them contributing to a fraternal world discussing the ethical paradoxes implied for organizations to adopt a fraternal relationship with stakeholders - the central premise of Fratelli Tutti. By focusing on the process of becoming fraternal, we encourage a deeper reflection about the embeddedness of organizations in their communities and network of stakeholders, which matters for how the organization is managed and also how it connects to the outside world for the sake of the common good.

We make two core contributions. First, we add to the literature by highlighting the relevance of Catholic Social Teaching and papal encyclicals to management scholarship in general and business ethics in particular (Bernacchio, 2019; Guitián, 2018; Melé \& Naughton, 2011; Tablan, 2015). We do so by (a) reflecting on the key dimensions that influence the relationships between organizations contributing toward the common good, (b) exploring the process of becoming a fraternal organization, and (c) uncovering the fundamental paradoxical dimensions of that journey. Our argument is twofold. First, we consider that being fraternal involves management challenges not represented in other ethical theories of corporate social responsibility, such as the normative stakeholder theory or the common good approach. For example, while the common good approach maintains that business, as "any other social group or individual in society," must contribute to the common good and wellbeing of society, "because it is a part of society" (Garriga \& Melé, 2004, p. 62), the paradoxical challenges involved in that endeavor have not been theorized. Second, the central process of becoming fraternal configures a distinct type of relationship with other organizational stakeholders that also deserves consideration.

Overall, this paper is positioned within, and broadens, the common good approach of corporate social responsibility (Garriga \& Melé, 2004). This approach is rooted in important philosophical traditions and has been assimilated into Catholic social thought as a key reference of business ethics (Albareda \& Sison, 2020; Frémeaux \& Michelson, 2017; Melé, 2020; Schlag \& Melé, 2020). According to this approach, business is a part of society and therefore must contribute to the common good: "Business should be neither harmful to nor a parasite on society, but purely a positive contributor to the wellbeing of the society" (Garriga \& Melé, 2004, p. 62). We contribute to this approach in two ways. First, we discuss Fratelli Tutti as an inspiring touchstone of that approach. Second, we advance that such an endeavor is pervaded with paradoxical challenges that have been understudied.

The paper is organized as follows. We first position our approach within Catholic Social Teaching and summarize how encyclicals have espoused a notion of integral human development that matters for how organizations operate. We 
then focus on Fratelli Tutti and provide a summary of its main contents. Then, we clarify our method: after explaining how we adopted an inductive approach to analyze the Encyclical's content, we describe the structure and key ideas of Fratelli Tutti relating to fraternal organizations. Mindful of the context of this publication, we translate the key ideas of the encyclical into themes that resonate with organization theory, introducing a set of ideas around community, the common good, and fraternity. We then take a step forward to look into the organizational context by highlighting and reflecting on key management and business ethics implications associated with developing a fraternal organization. Finally, we discuss several paradoxical challenges associated with the process of becoming fraternal. In doing so we adopt both a normative approach (i.e., we defend that organizations should operate as fraternal) and a descriptive one (i.e., we describe how such a normative approach is rife with tensions and paradox).

\section{Encyclicals and the Notion of Integral Human Development}

Papal encyclicals in general and social encyclicals in particular are important landmarks in the way the Catholic Church interacts with the world. Derived from the Greek words en kyklo (meaning "in the circle"), an enkyklike epistole constitutes a letter to be sent to everyone in the circle. Encyclicals bring together reflections, observations of the world, annotations about the (re)interpretation of Catholic Social Teaching in the present context and, of course, recommendations about how to live a more fruitful life (Sison \& Fontrodona, 2011). Social encyclicals have a long tradition in the Church, with scholarship attributing particular importance to Rerum Novarum written by Pope Leo XIII (1891) on the conditions of workers of post-industrial revolution factories (Melé \& Naughton, 2011).

Pope Francis has so far published three encyclicals, all focusing on different matters. In his first encyclical letter, Lumen Fidei, Francis invites Christians to rethink the value, relevance, and application of their own faith by questioning how faith is supporting each person to build the city of God (Pope Francis, 2013). That encyclical was followed by the surprising launch of Laudato si"' (Pope Francis, 2015), a communication focusing on the urgent need to care for the Earth, our planet and common home. While for many Laudato si' was a surprise, to others it came as a natural step in Pope Francis's journey of taking faith out of the spaces that individuals often associate with religion and spirituality. In Laudato si', Francis builds upon the concept of integral human development, first introduced by Pope Paul VI (1967) in his Encyclical letter Populorum Progressio, when stating $(\S 14)$ :
The development We speak of here cannot be restricted to economic growth alone. To be authentic, it must be well rounded; it must foster the development of each man and of the whole man. As an eminent specialist on this question [Lebret, (1961, p. 28)] has rightly said: "We cannot allow economics to be separated from human realities, nor development from the civilization in which it takes place. What counts for us is maneach individual man, each human group, and humanity as a whole'.

Laudato si' links the development of the whole person to the environmental surroundings, to caring about the "common home". From a business scholarship perspective, Laudato $s i$ ' has questioned how the natural resources have been considered from a human perspective (Rousseau, 2017). Both implicitly and explicitly, Laudato si' is also remarkable in pointing out that the "common home" is the habitat that human beings and businesses must respectfully preserve. For Pope Francis, the economic, social, and technological spheres are intimately connected and work together toward integral human development.

As Pope Francis continues to expose an alternative view grounded in Catholic Social Teaching through his encyclicals, we continue to update the organizational implications of Francis' proposal by drawing on the latest addition. Fratelli Tutti is particularly timely because it addresses the social dimensions of life during a time characterized by a paradoxical challenge: while the world's population has been asked to socially (and physically) distance from one another, nurturing a community spirit and a sense of fraternity is necessary to help and alleviate many issues of our current time. Pope Francis (2020b) himself wrote in the New York Times that " $[t]$ he pandemic has exposed the paradox that while we are more connected, we are also more divided" (p. SR3).

In this work we explore what Francis' recent encyclical means for organizations and discuss several and often paradoxical challenges emerging from the notion of organizations becoming fraternal. In doing so we also consider the several warnings to organizations included in the encyclical. In his well-known style, Pope Francis shows no hesitation in criticizing some of the power that organizations hold and use in an egotistical manner, the way some of these organizations treat their employees, and the role of organizations in society (Fontrodona \& Sison, 2006).

From an organizational standpoint, scholarship has dedicated substantial debate to understand how these letters and encyclicals can influence and shape important organizational domains. As an example, the Journal of Business Ethics has dedicated a special issue to Caritas in Veritate (Pope Benedict XVI, 2009), edited by Melé and Naughton (2011). This special issue featured work describing the implications for understanding humanistic economics (Grassl \& 
Habisch, 2011), the importance of alternative paradigms based on gift (Faldetta, 2011) and the common good (Sison \& Fontrodona, 2013), and implications for transparency in business (Vaccaro \& Sison, 2011), among others. Taken together, what this academic work suggests is that Catholic thought can configure a view of management that departs from established models, offering alternatives to managers and organizations (Grassl \& Habisch, 2011). Also salient are the business ethics implications of these alternative proposals rooted in an understanding that solid moral foundations are needed for advanced business ethics (Klein \& Laczniak, 2013; Melé \& Naughton, 2011).

Inspired by the work of Grassl and Habisch (2011), which derives implications for management and business ethics from Caritas in Veritate (Pope Benedict XVI, 2009), we take a similar approach to the work of Pope Francis and his encyclical Fratelli Tutti. Our argument is structured in two steps. Following a content analysis of Fratelli Tutti (Table 1), we identify four key dimensions that have resonance for and in organizations (Fig. 1). Then, we argue that these key dimensions are the building blocks of a fourfold cyclical process aimed at making organizations better engines for the common good (Fig. 2). We also discuss the paradoxes, i.e., the persisting dual obligations (Berti et al., 2021), associated with each of these blocks and the ethical implications of these paradoxes.

\section{Fratelli Tutti for Business Organizations}

Fratelli Tutti were the words used by Saint Francis himself to connect with his brothers and sisters. Through the expression Fratelli Tutti, Pope Francis explains: "Saint Francis expressed the essence of a fraternal openness that allows us to acknowledge, appreciate and love each person, regardless of physical proximity, regardless of where he or she was born or lives" $(\S 1)$. In other words, the invitation is for each of us to advance ways in order to make our relationships more just and fraternal.

While it can be argued that, from an organizational perspective, a focus on relationships is nothing new (Klein \& Laczniak, 2013), we see the encyclical as an invitation to reflect on the potential benefits of understanding organizations as relevant, if not critical, fraternal engines working toward the common good. Adopting this stance has the potential to shift the current focus from the nature and role of our fraternal relationships to the meaning, purpose, and impact that these relationships can bring to workplaces and society (not just at the individual level but also at the organizational one). Francis goes beyond reinforcing the already known effect that fraternal relationships can have. Rather, his invitation implies that fraternal organizations caring for the common good contribute to fraternal relationships between individuals, between individuals and organizations, between organizations within societies, and even between societies.

Fratelli Tutti is written in 287 paragraphs divided into eight chapters. Focused on introducing the foundations of what a truly fraternal world can look like, it begins by considering what is holding the world back in the development of universal fraternity. This description of the obstacles to a fraternal world can be found in chapters one to four. In the remaining chapters, Pope Francis advances possibilities to develop a more fraternal world building on dialogue, decisions toward peace, better political involvement, and contributions from religions. Speaking beyond the Catholic corporate world, it is clear that not all chapters address issues linked to organizational life. However, overall, they represent a holistic perspective about how human beings, both individually and collectively, as social, political, or economic actors, must interact fraternally (Pope Francis, 2020a, §8):

It is my desire that, in this our time, by acknowledging the dignity of each human person, we can contribute to the rebirth of a universal aspiration to fraternity. (...) Let us dream, then, as a single human family, as fellow travelers sharing the same flesh, as children of the same Earth which is our common home, each of us bringing the richness of his or her beliefs and convictions, each of us with his or her own voice, brothers and sisters all.

Fratelli Tutti is thus a doctrine-based manifesto with implications for business organizations. As some management and organization scholars (e.g., Maak et al., 2021; Pfeffer, 2015; Tsui et al., 2018) have suggested, business organizations could and should learn from the teachings of Pope Francis, including Fratelli Tutti. Rather than describing what each chapter can mean for organizational life, we focus on key dimensions that emerge from our interpretation of $\mathrm{Fra}$ telli Tutti and that have clear implications for organizational life. A deep analysis of these dimensions suggests that practicing the teachings of Pope Francis is complex and fraught with tensions and paradoxes. While acknowledging that such a paradoxicality is not new, and that other (normative and descriptive) ethical approaches, such as the stakeholder one (Hahn et al., 2015; Rego et al., 2021; Waldman \& Bowen, 2016), are also imbued with tensions and paradoxes, we consider that at least some of the paradoxical implications of Fratelli Tutti for managing organizations are idiosyncratic and worth being explored.

\section{Method}

Empirically, we approached our aim drawing upon the tested Gioia methodology (Gioia et al., 2013), which reduces qualitative data to meaningful theoretical categories. We began 
Table 1 Representative quotes of Fratelli Tutti - a sample of raw data

Key dimension \#1: building a fraternal society working toward the common good

\#1.1. "Here, economic negotiations do not work. Something else is required: an exchange of gifts for the common good. It may seem naïve and utopian, yet we cannot renounce this lofty aim." (\$190)

\#1.2. "An economy that is an integral part of a political, social, cultural and popular program directed to the common good could pave the way for "different possibilities which do not involve stifling human creativity and its ideals of progress, but rather directing that energy along new channels' [Pope Francis, 2015]”. (\$179)

\#1.3. "Indeed, 'without internal forms of solidarity and mutual trust, the market cannot completely fulfil its proper economic function. And today this trust has ceased to exist' [Pope Benedict XVI., 2009]”. (168)

\#1.4. "Instead, "what is needed is a politics which is far-sighted and capable of a new, integral and interdisciplinary approach to handling the different aspects of the crisis' [Pope Francis, 2015]”. ( $\$ 177)$

\#1.5. "I would repeat that 'true statecraft is manifest when, in difficult times, we uphold high principles and think of the long-term common good' [Pope Francis, 2015]". (\$178)

\#1.6. "Yet beyond this, those who love, and who no longer view politics merely as a quest for power, 'may be sure that none of our acts of love will be lost, nor any of our acts of sincere concern for others'. [Pope Francis, 2015]" (§195)

Key dimension \#2: reframing the essence of organizations in society

\#2.1. "What we need in fact are states and civil institutions that are present and active, that look beyond the free and efficient working of certain economic, political or ideological systems, and are primarily concerned with individuals and the common good". (\$108)

\#2.2. "Business abilities, which are a gift from God, should always be clearly directed to the development of others and to eliminating poverty, especially through the creation of diversified work opportunities". (§123)

\#2.3. "Life without fraternal gratuitousness becomes a form of frenetic commerce, in which we are constantly weighing up what we give and what we get back in return". (\$140)

\#2.4. "Individuals who possess this quality help make other people's lives more bearable, especially by sharing the weight of their problems, needs and fears. This way of treating others can take different forms: an act of kindness, a concern not to offend by word or deed (...$). " ~(\$ 223)$

\#2.5. "In God's plan, each individual is called to promote his or her own development, and this includes finding the best economic and technological means of multiplying goods and increasing wealth". (§123)

\#2.6. "If one does not acknowledge transcendent truth, then the force of power takes over, and each person tends to make full use of the means at his disposal in order to impose his own interests or his own opinion, with no regard for the rights of others". (\$273)

Key dimension \#3: redefining the connection of organizations with neighbors through adopting a fraternal approach

\#3.1. "So, this encounter of mercy between a Samaritan and a Jew is highly provocative; (...) It gives a universal dimension to our call to love". $(\S 83)$

\#3.2. "Hence there is an aspect of universal openness in love that is existential rather than geographical. It has to do with our daily efforts to expand our circle of friends, to reach those who, even though they are close to me, I do not naturally consider a part of my circle of interests." $(\$ 97)$

\#3.3. "If a certain kind of globalization claims to make everyone uniform, to level everyone out, that globalization destroys the rich gifts and uniqueness of each person and each people". (\$100)

\#3.4. "Yet it is impossible to be 'local' in a healthy way without being sincerely open to the universal, without feeling challenged by what is happening in other places, without openness to enrichment by other cultures, and without solidarity and concern for the tragedies affecting other peoples". (\$146)

\#3.5. "Seen from the standpoint not only of the legitimacy of private property and the rights of its citizens, but also of the first principle of the common destination of goods, we can then say that each country also belongs to the foreigner, inasmuch as a territory's goods must not be denied to a needy person coming from elsewhere." (\$124)

\#3.6. "The right to private property can only be considered a secondary natural right, derived from the principle of the universal destination of created goods. This has concrete consequences that ought to be reflected in the workings of society." (\$120)

Key dimension \#4: construction of fraternal community

\#4.1. "Solidarity means much more than engaging in sporadic acts of generosity. It means thinking and acting in terms of community. It means that the lives of all are prior to the appropriation of goods by a few". ( $\$ 116)$

\#4.2. "Unlike disagreement and conflict, persistent and courageous dialogue does not make headlines, but quietly helps the world to live much better than we imagine." ( $\$ 198)$

\#4.3. "Let us not forget that 'peoples that abandon their tradition (...) allow others to rob their very soul, end up losing not only their spiritual identity but also their moral consistency and, in the end, their intellectual, economic and political independence'. [Cardinal Raúl Silva Henríquez, 1974]" (\$14)

\#4.4. "To care for the world in which we live means to care for ourselves. Yet we need to think of ourselves more and more as a single family dwelling in a common home". (\$17)

\#4.5. "A plan that would set great goals for the development of our entire human family nowadays sounds like madness. We are growing ever more distant from one another, while the slow and demanding march towards an increasingly united and just world is suffering a new and dramatic setback". (\$16) 
Table 1 (continued)

\#4.6. "A living and dynamic people, a people with a future, is one constantly open to a new synthesis through its ability to welcome differences. In this way, it does not deny its proper identity, but is open to being mobilized, challenged, broadened and enriched by others, and thus to further growth and development”. (\$160)

by reviewing the encyclical Fratelli Tutti from an organizational perspective, capturing the quotes that expressed relevance for the organizational domain (see Table 1). We assessed relevance as a multi-level phenomenon: for individuals working or participating in organizational life; for teams; for organizations as a unit themselves; and for the economic system in which organizations operate.

Our work then focused on categorizing the quotes. We sought for each category to remain faithful to the words and expressions used by Pope Francis. This first sift through the encyclical generated 24 first-order codes (Fig. 1) associated with the multi-level view of a fraternal organization. As explained above, we defined fraternal in this context as an organization working toward the common good - or, informally, the duty to love one's stakeholders (Kaptein, 2021). We then progressed looking for similarities across the firstorder codes, and similar first ${ }^{-}$order quotes generated secondorder labels. These second-order labels (11 in total) were the bridge between the encyclical quotes and a clearer view of what a fraternal organization could resemble. Our final step of the analysis consisted in building analytical links between the second-order categories to establish understanding of the four key abstract dimensions (i.e., third-order categories) of a fraternal organization: (1) building a fraternal society working toward the common good; (2) reframing the essence of organizations in society; (3) redefining the connection of organizations with neighbors through adopting a fraternal approach; and (4) building fraternal communities.

\section{Four Key Organizational Dimensions of Fratelli Tutti}

\section{Key Dimension \#1: Building a Fraternal Society Working Toward the Common Good}

One of the central messages of Fratelli Tutti refers to the intersection of politics, markets, and the role of the Church. Pope Francis sees these as reciprocal dimensions working together to achieve the common good. This focus on the common good may be seen as the guiding principle of the Encyclical. In establishing this relationship, Francis begins by exploring how politics and economics can work together to generate "an economy that is an integral part of a political, social cultural and popular program directed to the common good" $(\$ 179)$. This argument is then complemented with an invitation to consider critical and relevant alternatives to the present political and economic models: "Yet, beyond this, those who love, and who no longer view politics merely as a quest for power, may be sure that none of the acts of love will be lost" (\$195). Compassionate or agape love (Sprecher \& Fehr, 2005), as an essential dimension of the quest toward the common good, becomes the center of the relationship between the economy and politics (Pirson et al., 2021). This is also where the role of the Church, in defining, propelling, and sharing love, is fundamental to building the society that seeks the common good. The Church, Pope Francis argues, "can thus understand, from her own experience of grace and $\sin$, the beauty of the invitation to universal love" ( $\$ 278)$ that is extended to all that seek the common good.

The focus on the common good is a long tradition in the Church. In their work about common good and Pope Benedict's Caritas in Veritate, Sison and Fontrodona (2011) provide an historical view of the concept arguing that the common good is at the center of unity between politics and economy. They define common good in conformity with Pope Benedict XVI's $(2009, \S 7)$ perspective: as "the good 'of all of us', made up of individuals, families and intermediate groups who together constitute society" (see Sison \& Fontrodona, 2011, p. 101). From a Catholic Social Teaching standpoint, the idea of common good refers to "something that does not diminish when it is divided and distributed among many, and can thus be actually shared" (Sison \& Fontrodona, 2011, p. 101). Seeking organizational alternatives that contribute to the common good has implications for organizations at, at least, two interrelated levels. On a general level, it is important to assess how products and services are sustainable. Unsustainable products or services exhaust resources and, in doing so, cannot be shared in the future. Such a consequence makes our "common home" unsustainable, not just for individuals, but also for organizations and communities (Pope Francis, 2015). On a more ecological level, the invitation to organizations is to see markets functioning in a different way, where the balanced benefits for the many are more critical than the large benefits to the few. This systemic view of the benefits for the market appears to invite organizations to reflect on the power of networks in the pursuit of the common good, rather than aiming their agency power at imposing their own interests with no regard for communities. 

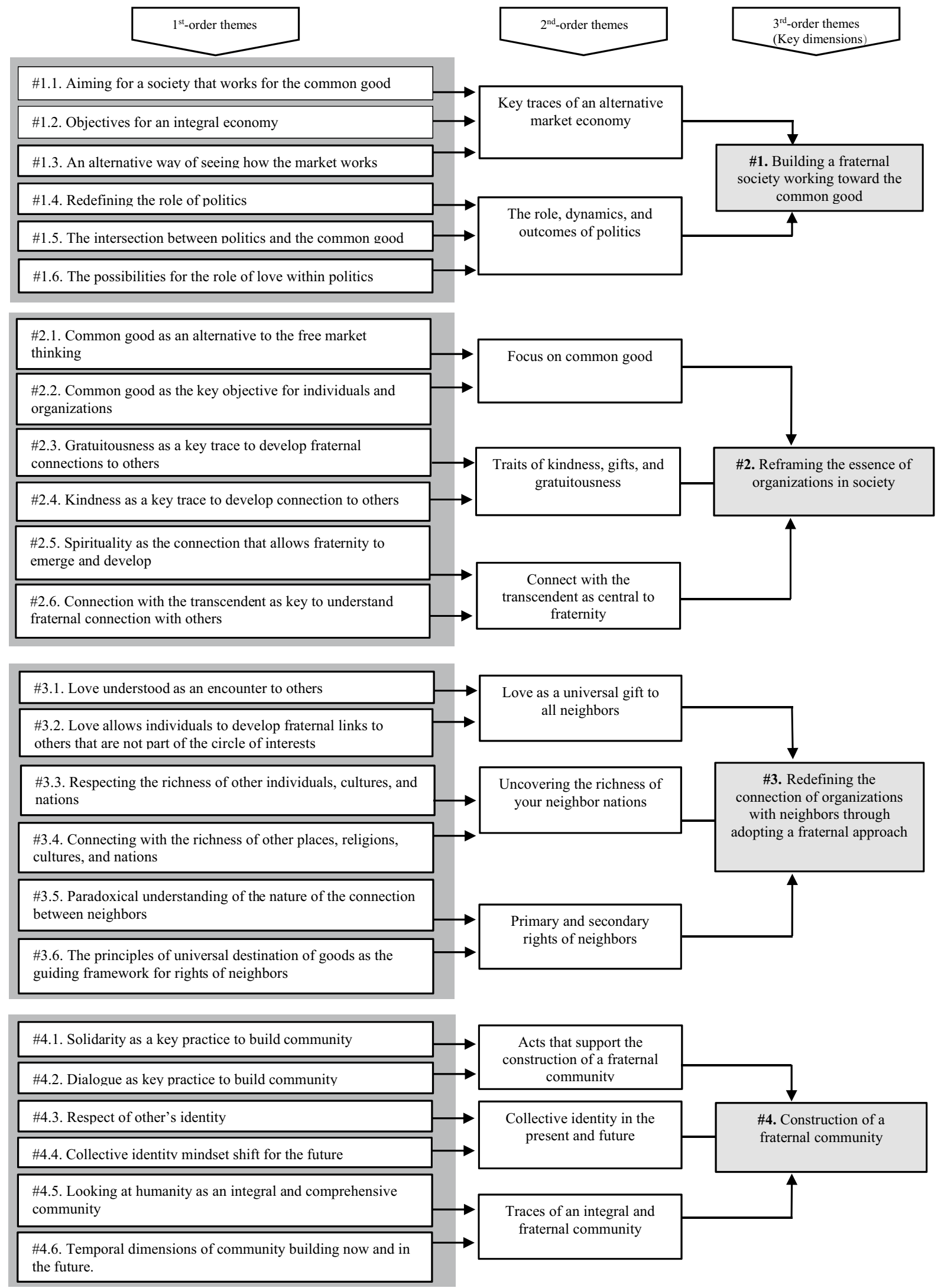

Fig. 1 Structure of the data (numbers associate themes with the representative quotes of Table 1) 
Fig. 2 The building blocks and the corresponding tensions of the process aimed at making organizations better engines for the common good, as inspired in Fratelli Tutti

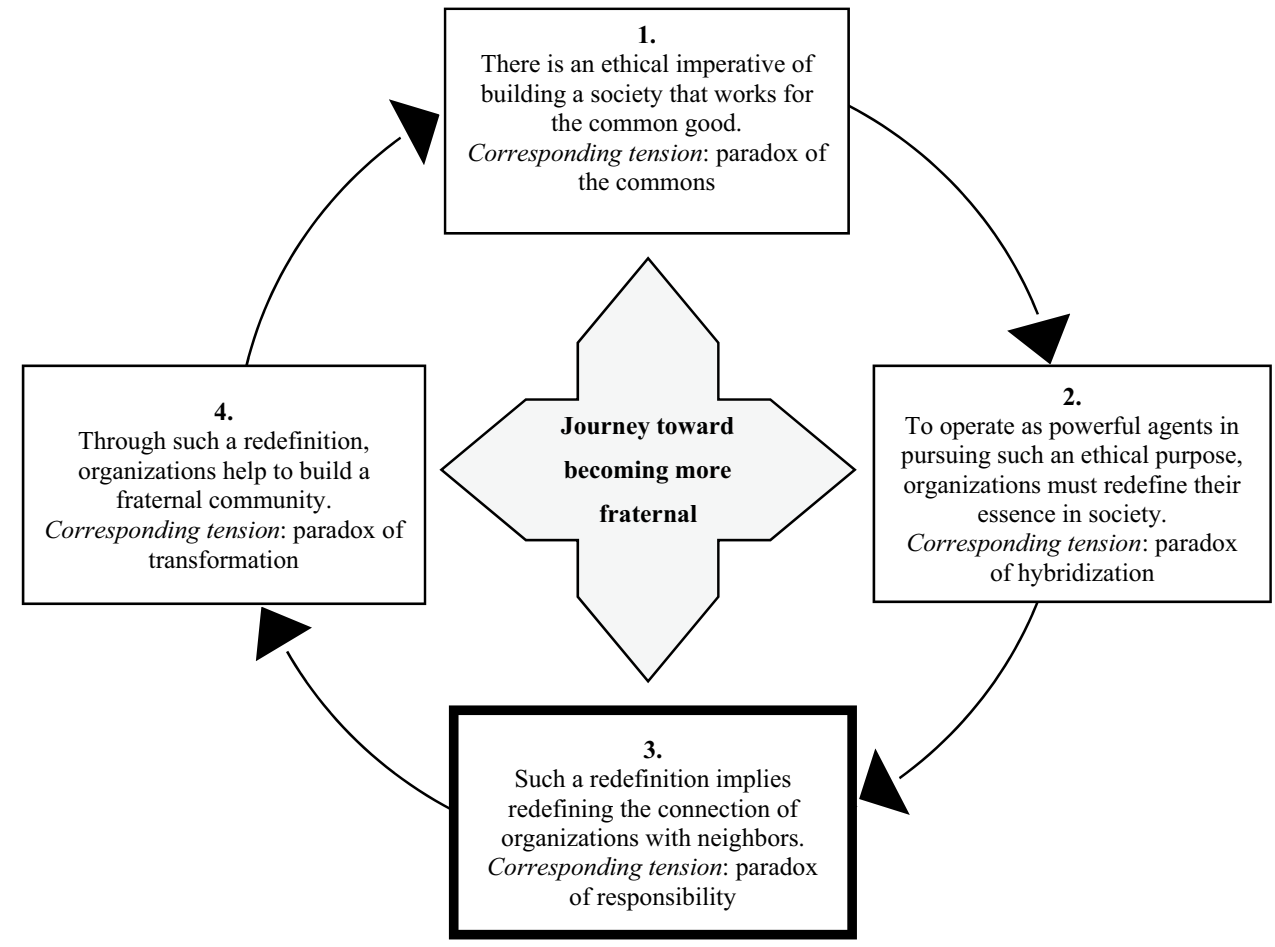

\section{Key Dimension \#2: Reframing the Essence of Organizations in Society}

The insights gathered from the encyclical Fratelli Tutti thus seem to test what type of organizational models are better suited to contribute to the development of solutions toward the common good. For example, in their work about Christian companies, Carradus et al. (2020) illustrate the practices adopted by large organizations that transform the business model toward a more explicit embrace of the common good. ${ }^{3}$ As Cardinal Turkson summarized in a recent encounter for economists, researchers, and change agents sponsored by Pope Francis, organizations should focus on "producing services that serve, products that are good and wealth that is rich" (Turkson, 2020) - or, in a slightly different formulation, goods that are truly good and services that truly serve (Goodpaster, 2011). In doing so, organizations will operate in a way that clearly contributes toward the common good.

\footnotetext{
${ }^{3}$ Another example is The Council for Inclusive Capitalism, "a movement of the world's business and public sector leaders who are working to build a more inclusive, sustainable, and trusted economic system" (https://www.inclusivecapitalism.com/). It illustrates the search for solutions toward the common good. Allegedly, the coalition's leaders had taken up the challenge of making capitalism a "more inclusive instrument for integral human wellbeing" (Pope Francis, in Edgecliffe-Johnson 2020, p. 6).
}

This radical change toward the common good proposed by Francis is rooted on gift and gratuitousness (Faldetta, 2011). This logic of gift and gratuitousness opposes the logics of the market (exchange) and the state (obligation) (Faldetta, 2011). From an organizational perspective, the logic of gift might be difficult to operationalize as most business relationships are based on market logics, such as transactions and price mechanisms, but the need for new logics has been discussed and experimented with: B-Corps, cooperatives, and circular economy organizations are expressions of these endeavors. To explain how the logic of gift works, Faldetta (2011) uses the example of the relationship between artist and art buyer, but one can imagine other contexts in which the experience of transaction itself, as well as the reputation, use, and so forth, matter more than the product itself. The logic of gift allows the buyer to use more than just the product, and the provider to receive more than just the revenue associated with the transaction.

More widely, what the logic of gift does is to question the internal logic associated with the purpose of each organization reframing their essence. The purpose of organizations has been a much-debated topic in recent literature (Basu, 2019; Hollensbe et al., 2014), with scholars noting how transforming the heart of the organization can change the way it interacts with society. Would society become more fraternal and just if more organizations and their leaders adopted a logic of gift? What would that entail? The encyclical provides a partial answer to this question. According to Pope Francis $(\S 123)$, in order to promote fraternity in our 
"common home," human beings are called upon to promote their own development, "and this includes finding the best economic and technological means of multiplying goods and increasing wealth." He then emphasizes that individuals endowed with the gift of business abilities "should always be clearly directed to the development of others and to eliminating poverty, especially through the creation of diversified work opportunities."

The values explicitly mentioned by Pope Francis underpin an individual search for transcendence that is also lacking. Acknowledging that "transcendent truth" is the opposite of embracing relativism as a moral compass (\$209), Francis observes that "If one does not acknowledge transcendent truth, then the force of power takes over, and each person tends to make full use of the means at his disposal in order to impose his own interests or his own opinion, with no regard for the rights of others" (\$273). ${ }^{4}$ Such "transcendent truth" is thus critical in redefining human purpose beyond individualism that can lead to systematic change. This departure from individualism leaves no doubt regarding what the purpose of organizations should be; it points out how important it is instead that organizations reframe their essence in order to contribute to society in a different way.

\section{Key Dimension \#3: Redefining the Connection of Organizations with Neighbors Through Adopting a Fraternal Approach}

Developing a fraternal world means, for sure, developing distinct relationships with those that surround us. For organizations, "those that surround them" are stakeholders that the organization treats as neighbors, as discussed above. A fraternal organization thus operates as a neighbor that loves fraternally other neighbors (Pope Francis, 2020a). In this regard, Pope Francis asks a critical question in the second chapter of the encyclical. The question "Who is our neighbor?" summarizes a key question for organizations that feel called to build a more fraternal world.

The parable of the good Samaritan, which Francis uses to exemplify two possible attitudes toward the outcasts of the world, helps to redefine the concept of fraternal connection with neighbors in which the rights, benefits, and responsibilities are well established and enacted, rather than merely used to instrumentally convey an image of being a "right" organization. In that parable (Luke Gospel, 10: 25-375), told by Jesus in the Gospel of Luke, a traveler going down from Jerusalem to Jericho is attacked by robbers. Stripped

\footnotetext{
${ }^{4}$ Lectio Divina, Pontifical Lateran University, Rome (26 March 2019): L'Osservatore Romano, 27 March 2019, p. 10.
}

of clothing, beaten, and left half dead alongside the road, he is in need of help. While both a Jewish priest and a Levite (a priest's assistant) pass by without offering to help the injured man, a Samaritan (Samaritans were hated by the Jews) stopped and took care of him. Jesus told the parable in response to a question from a lawyer: "who is my neighbor?" The parable's message is that the neighbor is the one who shows mercy by helping the injured fellow man - the Samaritan, in that case. The neighbor is indeed the one who loves the stranger, the other, whoever he/she is. Related to this, Pope Francis grounds this renewed relationship with neighbors in love. Love (a word that appears 125 times in the Encyclical) allows for fruitful and rich relationships. In Francis' own words, love allows that one remains "increasingly directed towards others, considering them of value, worthy, pleasing and beautiful apart from their physical and moral appearances" (\$94). Francis continues:

Our love for others, for who they are, moves us to seek the best for their lives. Only by cultivating this way of relating to one another will we make possible a social friendship that excludes no one and a fraternity that is open to all. (§94).

Love is therefore the key ingredient that underpins the relationship with neighbors. As explained by Argandoña (2011), (agape) love supplements a market view that allows firms to see beyond profits and gains. What the encyclical demonstrates is that love is the conduit for organizations to transcend their own interest to focus on the common good. In turn, this shapes the practices enacted by the company that develops an identity as neighbor, working toward common objectives.

This alignment through love across organizations that are neighbors supports a dual movement of discovery and acceptance. On the one hand, love allows neighbors to build understanding and experience regarding the uniqueness of the gifts offered by other organizational neighbors sharing the same path (Sasaki et al., 2019). This in turn offers them the opportunity to connect with neighbors establishing the necessary rights and responsibilities leading to a healthy pursuit of the common good. Principles such as the universal destination of goods are proposed as a key framework to guide rights and responsibilities of neighbors collectively working toward the common good. As Pope Francis summarizes ( $\$ 120)$, "The principle of the common use of created goods is the "first principle of the whole ethical and social order' (Saint John Paul II, 1981, §19).”

\footnotetext{
5 The Gospel of Saint Luke may be found, e.g., in the website of the US Conference of Catholic Bishops: https://bible.usccb.org/bible/ luke/10?25=\#50010025.
} 


\section{Key Dimension \#4: Building a Fraternal Community}

One of the most striking insights of COVID-19 is that no person, organization, country, or society can isolate themselves to the degree that ensures complete safety. The systemic interconnection of the world makes it difficult if not impossible to isolate salvation. The world can only save itself as one. Failing that, it can be destroyed as one. Businesses and managers should be aware of that condition not just during these critical times. The fact is that, as Pope Francis has observed, if businesses do not care about the "common home," perverse consequences will fall on all of us. Ryuzaburo Kaku (president of Canon from 1977 to 1989, chairman from 1989 to 2007, and then honorary chairman of the board), put it plainly when defending to put kyosei (the Japanese word for "living and working together for the common good"6; see also Boardman \& Kato, 2003) at the heart of the business credo:

Many companies around the world believe that they have a moral duty to respond to global problems such as Third World poverty, the deterioration of the natural environment, and endless trade battles. But few have realized that their survival actually depends on their response. (...) To put it simply, global companies have no future if the earth has no future. (Kaku, 1997, p. $55)$.

The interconnectedness that underpins this sense of wholeness is crucial for the way individuals behave, organizations exchange products and services, and the world functions as a unified system. At the heart of this interconnectedness is a deep sense of global community. A community that is built and renewed on a collective identity for which the "concept of people is in fact open ended. A living and dynamic people, a people with a future, constantly open to a new synthesis through its ability to welcome differences" (\$160). A community is "persistent and courageous in dialogue (...) and quietly helps the world to live much better than we imagine" (\$198). In detailing these key traits of the global community, Francis paves the way for a roadmap leading to fraternity and social encounter at the local, country, and world levels. Indeed, the Pope invites the multiple communities "to look beyond themselves and the group to which they belong" to start building a distinct sense of community (§117).

However, Francis also recognizes that there are essential dimensions to the development of these fraternal communities. In this regard, emphasis is put on solidarity, dialogue, and respect as the foundations for a collective mindset shift occurring now and in the future. These traces are crucial to the development of a fraternal community working toward the common good.

The direct implication to organizations concerns the role they assume in developing internal and external organizational communities. While it is positive to see how large corporate organizations have created advanced communities of practice that are rewarded for solving complex problems (Agterberg et al., 2010; Wenger \& Snyder, 2000), less appears to have been done by organizations that dedicate their time to solve world related and complex problems, commonly known as grand challenges. Indeed, in their essay about the relevance of management research for tackling global societal challenges, George et al. (2016) identify a framework that can be adopted by organizations that engage in addressing these issues. What is particularly noteworthy for our work is how those authors highlight the role of multilevel actions organized across distinct actors. The development of these organizational communities tackling common problems is clearly one strong invitation of the encyclical Fratelli Tutti.

\section{Paradoxes of working toward the common good}

What our analysis suggests is a four-stage cyclical process through which organizations can respond to this imperative of contribution toward society and the common good. First, building a society that works for the common good is an ethical imperative for business organizations. Second, to operate as powerful agents in enacting such an imperative, organizations must redefine their essence in society. Third, such a redefinition implies operating as good neighbors and reestablishing the connection of organizations with neighbors. Fourth, through such a redefinition, organizations contribute to the building of an interconnected community, thereby enacting and nurturing the ethical imperative for the sake of the common good. Previous work has already established how organizations are responding to changes in society by involving themselves in developing measures to work toward the sustainable development goals (Ferraro et al., 2015; George et al., 2016). However, our work goes further by tapping some paradoxical underpinnings of the four-stage cycle of engaging in society through the search for the common good (Melé, 2009; Sison \& Fontrodona, 2013). In short, the four-stage process of fraternal organizing is a paradoxical undertaking.

\footnotetext{
${ }^{6} \mathrm{See}$ https://sg.canon/en/campaign/business-insight/events/what-iskyosei.
} 


\section{The Ethical Imperative of the Common Good: The Paradox of the Commons}

The imperative of contributing toward the common good is the starting point of our cyclical process, which is consistent with the path of the Kyosei (Boardman \& Kato, 2003; Kaku, 1997), as mentioned above. As theory and organizational practice have indicated, society is converging around the need to work toward the common good (Albareda \& Sison, 2020). Indeed, the global experience of the COVID-19 pandemic has reminded all global actors that humankind needs to work toward the common good if it is to overcome challenges of this nature (Grewatsch \& Sharma, 2020; Howard-Grenville 2020). Pope Francis himself (2020b, p. SR3) wrote that.

(...) the pandemic has reminded us that no one is saved alone. What ties us to one another is what we commonly call solidarity. Solidarity is more than acts of generosity, important as they are; it is the call to embrace the reality that we are bound by bonds of reciprocity. On this solid foundation we can build a better, different, human future.

Only by acting on this imperative to work toward the common good will organizations enact their fraternity to the point that societal issues become addressed in an environmentally, economically, and socially sustainable way (George et al., 2016). However, as there are multiple ways of (or interpretations about) becoming fraternal, different approaches might lead to fractures across organizations collaborating toward the common good within the same community. Indeed, this intrinsic connection with the community entails a critical paradox regarding the notion of the commons. On the one hand, organizations must develop practices that ensure their own sustainability (as well as the one of neighbors such as employees, customers, and suppliers), and that is likely to entail using community resources for their own individual good. On the other hand, communities thrive in their efforts toward the common good only if common resources are leveraged, maintained, and developed over time. This means spending capital (human, social, technological, financial, etc.) in developing common interests. For example, by investing in the education of the community's members, the organization may obtain benefits from having more educated and qualified employees. However, if the organization refrains from making such an investment because it also benefits competitors, the consequence may be a "tragedy" for the community.

\section{Redefining the Essence of Businesses in Society: the Paradox of Hybridization}

The imperative of contributing toward the common good has provoked profound changes in the way companies understand their role within society (Handy, 2002; Hollensbe et al., 2014; Kurtzman \& Goldsmith, 2013). The corporate world has, at its best, energetically searched for ways of adopting a higher purpose (Mayer, 2021; Quinn \& Thakor, 2018). Cases such as the Business Roundtable (BRT) manifesto indicate that there is momentum toward enacting a purpose that transcends returning profit to shareholders. This will naturally lead to the redefinition of the essence of commercial organizations, requiring the development of new relationships with society at different levels. Note, however, that those manifestos and other initiatives such as the Council for Inclusive Capitalism, while being meritorious, are not sufficient. In some cases, the signatures appear to be empty rhetoric, i.e., image without substance (Goodman, 2020, p. B1):

In late August, as Salesforce celebrated more than $\$ 5$ billion in quarterly sales, Mr. Benioff proclaimed validation. 'This is a victory for stakeholder capitalism,' he said in a television interview. The next day, in the midst of the pandemic, Salesforce informed 1,000 employees that their jobs were no longer needed.

Embodying organizations' role as change agents calls attention to the intrinsic redefinition of the way success is defined and measured. In this regard, organizations are called upon to generate impact in a meaningful and explicit way of operating as agents of change in their communities instead of just focusing on returning profits to shareholders. Changing the essence means an added focus on the environmental and social dimensions defended by Pope Francis. Business organizations are invited to change their very nature to be able to pursue additional objectives beyond profit. In doing so, organizations are faced with the paradox of hybridization, supporting a change of essence toward social and environmental benefits for the community, while preserving financial sustainability (Haigh et al., 2015). For organizations embracing this transition, the ethical imperative is one of authenticity (Jones \& Gautschi, 1988). To what degree can organizations be authentic regarding their sustainable ambitions when economic issues appear to be more valued than community culture, natural, and social capital (Peredo \& Chrisman, 2006)? 


\section{Operating as good Neighbors: the Paradox of Responsibility}

Redefining the essence of businesses will open new opportunities for organizations to become more active in the search for fraternal solutions. Organizations are also invited to review their role as neighbors working together with others within their communities toward the common good. The invitation by Pope Francis is that organizations replace their management of stakeholders underpinned by self-interest (Donaldson \& Preston, 1995; Mitchell et al., 1997) by a normative approach in which organizations conceive themselves as valuable neighbors in their communities. The invitation to understand others as part of the same fabric redefines the material and immaterial connections established within the community. The effort, however, is paradoxical and rich in tension, which helps to explain why good intentions and statements become, at least in some cases, empty words. As organizational paradox theory suggests, it is simpler to handle tensions by adopting an approach of either/or than one of both/and (Berti et al., 2021; Schad et al., 2016). When tensions of being a good neighbor and contributing toward the common good emerge, primacy often occurs as the more comfortable approach - a decision that has given rise to critical, skeptical, and even cynical perspectives about some signatories of the BRT. As Stern (2021, p. 14) argues,

The same sceptics might note that signatories to the BRT statement have not necessarily shown heightened awareness of all their stakeholders' needs. Amazon has resisted attempts by employees to win union recognition and has brought in a consultant famed for maintaining 'union free workplaces'. The board of JPMorgan Chase recently confirmed that stockholders come first and that other stakeholders have to wait in line. And yet its chief executive, Jamie Dimon, was a driving force behind the BRT statement.

Working toward the common good implies developing a relationship based on love as mutual care, dialogue, respect for diversity and richness of gifts and gratuitousness that might be understood at different levels across the community. Some neighbors might adopt a more loving connection with others based on their personal values, spiritual calling, or previous experiences, while other neighbors might feel less called to voluntarily work toward the common good. Indeed, this reminds us that organizations seeking to become more fraternal assume responsibility for creating ties that enable the welfare of many, in detriment to their sole benefit. Addressing this paradox of personal and shared responsibility entails critical ethical challenges. Should the rules of the common good be enforced across all neighbors? Does it make sense to consider that, because of a greater benefit to all the community members, the calling to be a good neighbor should be enforced (Sauser, 2005)? And if so, how does that impact the collective enterprise of contributing toward the common good?

\section{Building a Fraternal Community: The Paradox of Transformation}

While one can consider communities in isolation, rarely do organizations choose or control the individuals or companies that become their neighbors, and with whom they must collaborate toward the common good. Indeed, what the encyclical suggests is that being fraternal should impel organizations to connect with others at various levels. Francis (2020a) states "It is one thing to feel forced to live together, but something entirely different to value the richness and beauty of those seeds of common life that need to be sought out and cultivated" ( $\$ 31)$. Leveraging on the richness available across their communities often leads to building abundant links, initiatives, and projects that ultimately will transform the shape of the community. Fraternal neighbors thrive when the multiple parts of their ecosystem and community also thrive (O'Brien, 2009). As Pope Francis (2020a) shows, "The mere sum of individual interests is not capable of generating a better world for the whole human family" (\$105).

This configures a critical paradox related to transformation. On the one hand, organizations will need to meet and engage a number of times in joint efforts and initiatives in order to transform the community toward the common good. On the other hand, building a mindset toward the common good will also require extensive dialogue and understanding. Too many contacts and joint projects will distract the organization from its own identity, assuming a more collective expression across the community. This will potentially make it difficult to distinguish how its particular value adds to the construction and transformation of a fraternal community, leading to ethical questions regarding the respect and understanding of the degree of transformation that communities should adopt when moving collectively toward the common good. How can all members of the community move at the same pace? What shall the community do if one or more members cannot adopt a fraternal mindset? How shall the community reward the members that fully engage in fraternal activities? And should the community punish those that decide against it? 


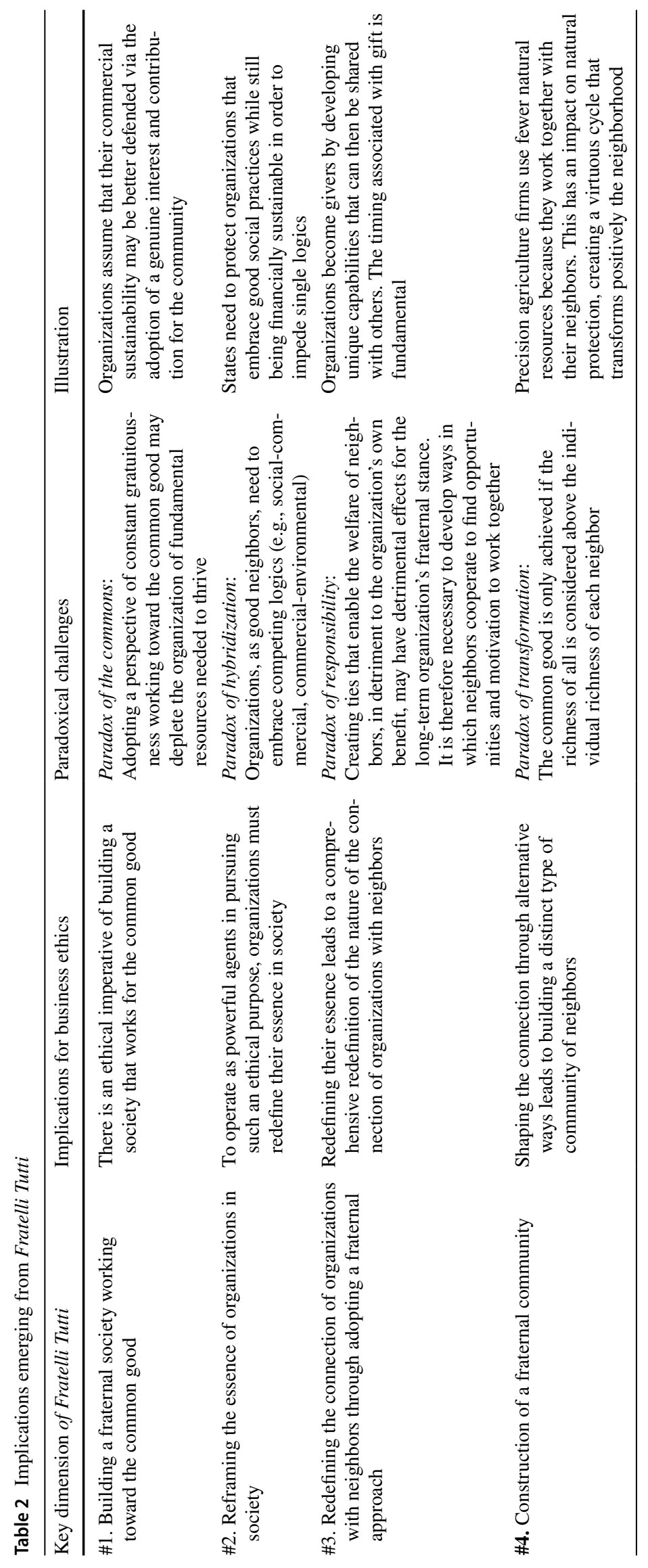




\section{Contributions and Practical Implications}

Our reflection on the implications of the process associated with becoming a fraternal organization and how that shapes the nature of the relationship with others within the organizational context (see a synthesis on Table 2) makes two important contributions to the literature. First, we contribute to the development of organization theory from a Catholic Social Teaching perspective, offering novel insights into established themes. We present a reconfiguration of the relational process articulating organizations that become fraternal through a focus on the common good. Understanding how organizations become fraternal helps to view the role of relational coordination as a process that crosscuts organizations, communities, sectors, and nations reaching shared goals (Bolton et al., 2021). Second, we build on the concept of becoming fraternal to uncover the paradoxical challenges associated with this process. In this respect, our work presents a more nuanced view of the common good associated with theories of corporate social responsibility (Garriga \& Melé, 2004), adopting both normative and descriptive stances.

A central element of our argument is that becoming fraternal is a journey, i.e., a process of creating an organizational endeavor in the direction of the common good among organizational neighbors that form part of the same community. It is a dynamic rather than a fixed state. Indeed, we conceptualize this process as a journey toward building an ideal of shared value that is underpinned by the key elements expressed in the encyclicals and that form the core of the current teaching of Pope Francis: culture of care/love, practice of fraternity, shared responsibility for resources, and signs of gratuitousness. Understanding fraternity and the process of becoming fraternal as a journey that builds upon the Catholic Social Tradition extends previous literature in its fundamental assumption regarding the nature of the relationships with others in the organizational landscape both internally and externally. Whereas past literature has often represented relationships with others in the community as transactional or an exercise in damage prevention or control (Jung \& Kim, 2016; Kerlin, 1997), our work draws upon the reflection proposed in the encyclical to describe how the process of becoming fraternal offers an opportunity to grow together toward the common good both commercially, organizationally, and ethically. In this regard we continue to show the relevance of Catholic Social Teaching and papal encyclicals to management scholarship (Klein \& Laczniak, 2013; Melé \& Naughton, 2011; Tablan, 2015) in general and in business ethics.

In addition, by understanding the process of becoming fraternal as an organizational journey, we offer a clear distinction from the concept of stakeholder management, which is currently popular in the literature discussing issues related to corporate social responsibility and the role of organizations in society (Hollensbe et al., 2014). While recent discussions have stressed how commercial organizations must respond to all stakeholders rather than just shareholders, and consequently include societal, environmental, and economic concerns in their practices, our work reveals a novel way of interpreting how organizations manage relationships with stakeholders. In this regard, we suggest that when becoming fraternal, organizations appear to develop distinct relationships with others sharing the same purpose and objective. Assuming that organizations sharing the journey toward the common good can be understood as neighbors in the broadest sense of the concept offered by Pope Francis, our work uncovers a category that cuts across stakeholders because of the focus on the common good (O’Brien, 2009; Yunus \& Weber, 2011). This implies that organizations must create a different relationship with neighbors, a relationship underpinned by a redefinition of their role in society and the desire to contribute to an interconnected community.

Our work also shows that the focus on the common good offers both paradoxical opportunities and challenges for both managerial practices and ethical decisions. Through the lens of paradox theory our work examines the tensions that underpin the construction of a virtuous relationship with others in the journey toward becoming more fraternal, observing that an interlinked array of tensions exists when organizations enact similar practices. By uncovering tensions and the implications for the relationships with other organizations and the market environment, we help to better understand intra-organizational tensions (Smets et al., 2019) as a critical factor in the management of solutions that address societal issues and the development of the common good. Our work also demonstrates that these paradoxes are part of the process, and therefore becoming fraternal requires practical wisdom (Aquinas, 1974; Bachmann et al., 2018; Rego et al., 2021). What we observe is that at the heart of becoming fraternal is a desire for transforming community whereby organizations take a central role in leading toward the common good. Greater effect is reached when this desire is assumed by all organizational neighbors - although such an assumption may be interpreted differently by different organizations with different and even conflicting perspectives about the most virtuous way to build a fraternal community.

Overall, we discuss the steps toward becoming fraternal as an organizational paradoxical process. The analysis conducted here leads us to defend a balanced approach between a normative perspective (according to which all organizations must operate as fraternal) and a descriptive one (organizations contextualize the most important practices 
that configure their role as neighbors working toward a fraternal community). This comprehensive view extends previous theories that have not engaged with the paradoxes and tensions associated with organizations working toward the common good.

For practice the above discussion suggests that, given the paradoxical element involved in the management of the fraternal organization, organizations need to dynamically balance, without solving (as paradoxes persist; e.g. Schad et al., 2016) the tensions involved in articulating multiple and competing interests. From this perspective managers may for example develop a dynamic view of "purpose" (Clegg et al., 2021), prioritizing different stakeholders in different circumstances, in order to better respond to pressing needs, instead of favoring a specific stakeholder, normally the shareholder. The fraternal organization is mindful of the fact that changing times change the order of priorities and resource allocation (including care and attention). This will invite business leaders to conceive their leadership as an exercise in the integration of competing needs (Cunha et al., 2021).

\section{Conclusion}

Becoming fraternal is an organizational journey offering the possibility of redefining both the role of organizations in society as well as the relationships between them. Such a fraternal approach, as inspired by Fratelli Tutti in particular, and Catholic Social Teaching in general, is crucial to address socio-economic and health dysfunctions (see, e.g., Payne, 2018; Russell, 2021; Wilkinson \& Pickett, 2009) that matter regardless of having or not having Catholic faith. However, such a journey is a process involving paradoxical challenges. It is said that "good fences make good neighbors" (Frost, 1914) but acknowledging the centrality of working toward the common good (O'Brien, 2009) as part of a process leading to deep fraternal relationships is much more critical and challenging. Overall, our argument defends that engaging in this journey is an answer to the ethical imperatives that currently exist in society in relation to working toward the common benefit of community as well as a way of understanding and addressing the key tensions that are encountered along the way in this journey. However, we are mindful that research on this topic is still in its infancy. Thus, we believe that the next logical step for research is to understand how organizations assess working toward the possibility of common good. If, as we mentioned above, "it is through dialogue that opposing forces find common ground and move forward together creating a more just and fraternal world," working toward the common goal, we see great promise in seeing how many more organizations seek to develop a more fraternal dialogue.
Acknowledgements This work was funded by Fundação para a Ciência e a Tecnologia (UID/ECO/00124/2019, UIDB/00124/2020, UID/ GES/00731/2019, UID/GES/00315/2019, and Social Sciences DataLab, PINFRA/22209/2016), POR Lisboa and POR Norte (Social Sciences DataLab, PINFRA/22209/2016)

\section{Declarations}

Conflict of interest The authors declare that they have no conflict of interest.

\section{References}

Agterberg, M., van den Hooff, B., Huysman, M., \& Soekijad, M. (2010). Keeping the wheels turning: The dynamics of managing networks of practice. Journal of Management Studies, 47(1), $85-108$.

Albareda, L., \& Sison, A. J. G. (2020). Commons organizing: Embedding common good and institutions for collective action insights from ethics and economics. Journal of Business Ethics, 166(4), 727-743.

Aquinas, T. (1974). In: Gilby T. (Ed.) Summa theologiae (Vol. 36). Cambridge University Press.

Argandoña, A. (2011). Beyond contracts: Love in firms. Journal of Business Ethics, 99(1), 77-85.

Bachmann, C., Habisch, A., \& Dierksmeier, C. (2018). Practical wisdom: Management's no longer forgotten virtue. Journal of Business Ethics, 153(1), 147-165.

Barnett, M. L. (2014). Why stakeholders ignore firm misconduct: A cognitive view. Journal of Management, 40(3), 676-702.

Barnett, M. L., \& King, A. A. (2008). Good fences make good neighbors: A longitudinal analysis of an industry self-regulatory institution. Academy of Management Journal, 51(6), 1150-1170.

Basu, S. (2019). Corporate purpose: Why it matters more than strategy. Routledge.

Bernacchio, C. (2019). Pope Francis on conscience, gradualness, and discernment: Adapting Amoris Laetitia for business ethics. Business Ethics Quarterly, 29(04), 437-460.

Berti, M., Simpson, A. V., Cunha, M. P., \& Clegg, S. (2021). Elgar introduction to organizational paradox theory. Edward Elgar.

Boardman, C. M., \& Kato, H. K. (2003). The Confucian roots of business Kyosei. Journal of Business Ethics, 48(4), 317-333.

Bolton, R., Logan, C., \& Gittell, J. H. (2021). Revisiting relational coordination: A systematic review. The Journal of Applied Behavioral Science, 57(3), 290-322.

Carradus, A., Zozimo, R., \& Discua Cruz, A. (2020). Exploring a faith-led open-systems perspective of stewardship in family businesses. Journal of Business Ethics, 163(4), 701-714.

Clegg, S., Cunha, M. P., Rego, A., \& Santos, F. (2021). 'Open purpose': Embracing organizations as expressive systems. Organization Theory, 2(4), 26317877211054860.

Cremers, M. (2017). What corporate governance can learn from Catholic Social Teaching. Journal of Business Ethics, 145(4), 711-724.

Cunha, M. P., Clegg, S., Rego, A., \& Berti, M. (2021). Paradoxes of power and leadership. Routledge.

Cunha, M. P., Rego, A., \& Vaccaro, A. (2014). Organizations as human communities and internal markets: Searching for duality. Journal of Business Ethics, 120(4), 441-455.

Donaldson, T., \& Preston, L. E. (1995). The stakeholder theory of the corporation: Concepts, evidence, and implications. Academy of Management Review, 20(1), 65-91. 
The Economist. (2014). Francis, capitalism, and war: The pope's divisions. June 20th. https://www.economist.com/erasmus/ 2014/06/20/the-popes-divisions

Edgecliffe-Johnson, A. (2020). Pope Francis joins businesses and investors in mission to redeem capitalism. Financial Times, December 9, 6 .

Faldetta, G. (2011). The logic of gift and gratuitousness in business relationships. Journal of Business Ethics, 100(S1), 67-77.

Ferraro, F., Etzion, D., \& Gehman, J. (2015). Tackling grand challenges pragmatically: Robust action revisited. Organization Studies, 36(3), 363-390.

Fontrodona, J., \& Sison, A. J. G. (2006). The nature of the firm, agency theory and shareholder theory: A critique from philosophical anthropology. Journal of Business Ethics, 66(1), 33-42.

Frémeaux, S., \& Michelson, G. (2017). The common good of the firm and humanistic management: Conscious capitalism and economy of communion. Journal of Business Ethics, 145(4), 701-709.

Frost, R. (1914). Mending wall. In North of Boston. David Nutt Book Publishers.

Garriga, E., \& Melé, D. (2004). Corporate social responsibility theories: Mapping the territory. Journal of Business Ethics, 53, 51-71.

George, G., Howard-Grenville, J., Joshi, A., \& Tihanyi, L. (2016). Understanding and tackling societal grand challenges through management research. Academy of Management Journal, 59(6), $1880-1895$.

Ghoshal, S. (2005). Bad management theories are destroying good management practices. Academy of Management Learning and Education, 4(1), 75-91.

Ghoshal, S., \& Moran, P. (2005). Towards a good theory of management. In J. Birkinshaw \& G. Piramal (Eds.), Sumantra Ghoshal on management (pp. 1-27). FT/Prentice-Hall.

Gioia, D. A., Corley, K. G., \& Hamilton, A. L. (2013). Seeking qualitative rigor in inductive research: Notes on the Gioia methodology. Organizational Research Methods, 16(1), 15-31.

Goodman, P. S. (2020). Stakeholder capitalism falters in study. The New York Times, September 22, B1.

Goodpaster, K. E. (2011). Goods that are truly good and services that truly serve: Reflections on "Caritas in Veritate." Journal of Business Ethics, 100(1), 9-16.

Grassl, W., \& Habisch, A. (2011). Ethics and economics: Towards a new humanistic synthesis for business. Journal of Business Ethics, 99(1), 37-49.

Grewatsch, S., \& Sharma, G. (2020). How COVID-19 informs business sustainability research: It's time for a systems perspective. Journal of Management Studies, 58(2), 602-606.

Guitián, G. (2021). How financial institutions can serve the common good of society: Insights from Catholic Social Teaching. Business Ethics, the Environment \& Responsibility, forthcoming.

Guitián, G. (2018). Pope Francis and Catholic Social Teaching on Ecology. Worldviews, 22(2), 163-186.

Hahn, T., Pinkse, J., Preuss, L., \& Figge, F. (2015). Tensions in corporate sustainability: Towards an integrative framework. Journal of Business Ethics, 127(2), 297-316.

Haigh, N., Walker, J., Bacq, S., \& Kickul, J. (2015). Hybrid organizations: Origins, strategies, impacts, and implications. California Management Review, 57(3), 5-12.

Handy, C. (2002). What is a business for? Harvard Business Review, $80(12), 49-52$.

Hollensbe, E., Wookey, C., Hickey, L., George, G., \& Nichols, C. V. (2014). Organizations with purpose. Academy of Management Journal, 57(5), 1227-1234.

Howard-Grenville, J. (2020). Grand challenges, Covid-19 and the future of organizational scholarship. Journal of Management Studies. https://doi.org/10.1111/joms.12647
Jones, T. M., \& Gautschi, F. H. (1988). Will the ethics of business change? A survey of future executives. Journal of Business Ethics, 7(4), 231-248.

Jung, H.-J., \& Kim, D.-O. (2016). Good neighbors but bad employers: Two faces of corporate social responsibility programs. Journal of Business Ethics, 138(2), 295-310.

Kaku, R. (1997). The path of Kyosei. Harvard Business Review, JulyAugust, 55-63.

Kaptein, M. (2021). The moral duty to love one's stakeholders. Journal of Business Ethics. https://doi.org/10.1007/s10551-021-04897-y

Kerlin, M. J. (1997). From Kerlin's Pizzeria to MJK Reynolds: A Socratic and Cartesian Approach to Business Ethics. Journal of Business Ethics, 16, 275-278.

Klein, T. A., \& Laczniak, G. R. (2013). Implications of Caritas in Veritate for Marketing and Business Ethics. Journal of Business Ethics, 112(4), 641-651.

Kurtzman, J., \& Goldsmith, M. (2013). Common purpose: How great leaders get organizations to achieve the extraordinary. Jossey-Bass.

Lebret, L. J. (1961). Dynamique concrete du development. Les editions Ouvrierès.

Maak, T., Pless, N. M., \& Wohlgezogen, F. (2021). The fault lines of leadership: Lessons from the global Covid-19 crisis. Journal of Change Management, 21(1), 66-86.

Mayer, C. (2021). The future of the corporation and the economics of purpose. Journal of Management Studies, 58(3), 887-901.

McCarty, N., Poole, K. T., \& Rosenthal, H. (2016). Polarized America: The dance of ideology and unequal riches. Cambridge: MIT Press.

Melé, D. (2009). Integrating personalism into virtue-based business ethics: The personalist and the common good principles. Journal of Business Ethics, 88(1), 227-244.

Melé, D. (2020). Catholic social teaching and responsible management. In Research Handbook of Responsible Management (pp. 292-303). Edward Elgar Publishing.

Melé, D., \& Naughton, M. (2011). The Encyclical-Letter "Caritas in Veritate": Ethical Challenges for Business. Journal of Business Ethics, 100(S1), 1-7.

Mintzberg, H. (2009). Rebuilding Companies as Communities (pp 1-5). Harvard Business Review.

Mitchell, R. K., Agle, B. R., \& Wood, D. (1997). Toward a theory of stakeholder identification and salience defining the principle of who and what really counts. Academy of Management Review, $22(4), 853-886$.

O'Brien, T. (2009). Reconsidering the common good in a business context. Journal of Business Ethics, 85(S1), 25-37.

Payne, K. (2018). The broken ladder: How inequality affects the way we think, live, and die. Penguin.

Peredo, A. M., \& Chrisman, J. J. (2006). Toward a theory of community-based enterprise. Academy of Management Review, 31(2), 309-328.

Pfeffer, J. (2015). What Starbucks can learn from Pope Francis. Fortune, September 28. Retrieved December 3, 2021, from http:// fortune.com/2015/09/28/starbucks-pope-francis/.

Pickett, K. E., \& Wilkinson, R. G. (2015). Income inequality and health: A causal review. Social Science \& Medicine, 128, 316-326.

Pirson, M., Dessi, C., Floris, M., \& Giudici, E. (2021). Humanistic Management: What Has Love Got to Do with it? Humanistic Management Journal, 6(1), 1-4.

Pope Leo XIII. (1891). Rerum Novarum. Retrieved from http://www. vatican.va/content/leo-xiii/en/encyclicals/documents/hf_l-xiii_ enc_15051891_rerum-novarum.pdf

Pope Paul VI. (1967). Populorum Progressio. Retrieved from http:// www.vatican.va/content/paul-vi/en/encyclicals/documents/hf_pvi_enc_26031967_populorum.pdf 
Pope Benedict XVI. (2009). Caritas in Veritate. Retrieved from http:// www.vatican.va/content/benedict-xvi/en/encyclicals/documents/ hf_ben-xvi_enc_20090629_caritas-in-veritate.pdf

Pope Francis. (2013). Lumen Fidei. Retrieved from http://www.vatican. $\mathrm{va} /$ content/dam/francesco/pdf/encyclicals/documents/papa-franc esco_20130629_enciclica-lumen-fidei_en.pdf

Pope Francis. (2015). Laudato si' '. Retrieved from http://www.vatican. $\mathrm{va/content/dam/francesco/pdf/encyclicals/documents/papa-franc}$ esco_20150524_enciclica-laudato-si_en.pdf

Pope Francis. (2020a). Fratelli Tutti: on Fraternity and Social Friendship. Retrieved from http://www.vatican.va/content/francesco/en/ encyclicals/documents/papa-francesco_20201003_enciclica-frate lli-tutti.html

Pope Francis (2020b). A crisis reveals what is in our hearts. The New York Times, November 29, SR3.

Quinn, R. E., \& Thakor, A. (2018). Creating a purpose-driven organization. Harvard Business Review, 96(4), 78-85.

Rego, A., Cunha, M. P., \& Clegg, S. R. (2021). Exploring the paradoxical nature of responsible leadership. In N. Pless \& T. Maak (Eds.), responsible leadership (2nd ed.). Routledge.

Retolaza, J. L., Aguado, R., \& Alcaniz, L. (2019). Stakeholder theory through the lenses of Catholic Social Thought. Journal of Business Ethics, 157(4), 969-980.

Rousseau, H. E. (2017). Corporate Sustainability: Toward a Theoretical Integration of Catholic Social Teaching and the NaturalResource-Based View of the Firm. Journal of Business Ethics, 145(4), 725-737.

Russell, J. W. (2021). The politics of wealth and income inequality. In L. Chorbajian (Ed.), Power and inequality (pp. 113-123). Routledge.

Saint John Paul II (1981). Encyclical Letter Laborem Exercens. Retrieved December 3, 2021, from https://www.vatican.va/conte nt/john-paul-ii/en/encyclicals/documents/hf_jp-ii_enc_14091981_ laborem-exercens.pdf.

Sasaki, I., Ravasi, D., \& Micelotta, E. (2019). Family firms as institutions: Cultural reproduction and status maintenance among multicentenary shinise in Kyoto. Organization Studies, 40(6), 793-831.

Sauser, W. I. (2005). Ethics in business: Answering the call. Journal of Business Ethics, 58(4), 345-357.

Schad, J., Lewis, M. W., Raisch, S., \& Smith, W. K. (2016). Paradox research in management science: Looking back to move forward. Academy of Management Annals, 10(1), 5-64.

Schlag, M., \& Melé, D. (2020). Building institutions for the common good. The practice and purpose of business in an inclusive economy. Humanistic Management Journal, 5(1), 1-6.

Simpson, A. V., Cunha, M. P., \& Rego, A. (2015). Compassion in the Context of Capitalistic Organizations: Evidence from the 2011 Brisbane Floods. Journal of Business Ethics, 130(3), 683-703.

Sison, A. J. G., \& Fontrodona, J. (2011). The Common Good of Business: Addressing a Challenge Posed by «Caritas in Veritate». Journal of Business Ethics, 100(S1), 99-107.
Sison, A. J. G., \& Fontrodona, J. (2013). Participating in the Common Good of the Firm. Journal of Business Ethics, 113(4), 611-625.

Smets, M., Moss Cowan, A., Athanasopoulou, A., Moos, C., \& Morris, T. J. (2019). From taking to making paradox: A multi-level perspective on how CEOs balance nested paradoxes. Academy of Management Proceedings. https://doi.org/10.5465/AMBPP. 2019.112

Sprecher, S., \& Fehr, B. (2005). Compassionate love for close others and humanity. Journal of Social and Personal Relationships, 22(5), 629-651.

Stern, S. (2021). The board's futile pursuit of purpose. Financial Times, February 22, 14.

Stockhammer, E. (2015). Rising inequality as a cause of the present crisis. Cambridge Journal of Economics, 39(3), 935-958.

Tablan, F. (2015). Catholic social teachings: Toward a meaningful work. Journal of Business Ethics, 128(2), 291-303.

Tornielli, A., \& Galeazzi, G. (2015). This economy kills: Pope Francis on capitalism and social justice. Liturgical Press.

Tsui, A. S., Enderle, G., \& Jiang, K. (2018). Income inequality in the United States: Reflections on the role of corporations. Academy of Management Review, 43(1), 156-168.

Turkson, C. P. (2020). Opening Speech - Economy of Francesco. Presented at the Economy of Francesco Conference, Assisi.

Vaccaro, A., \& Sison, A. J. G. (2011). Transparency in Business: The Perspective of Catholic Social Teaching and the "Caritas in Veritate." Journal of Business Ethics, 100(S1), 17-27.

van Marrewijk, M. (2004). A Value Based Approach to Organization Types: Towards a coherent set of stakeholder-oriented management tools. Journal of Business Ethics, 55(2), 147-158.

Waldman, D. A., \& Bowen, D. E. (2016). Learning to Be a ParadoxSavvy Leader. Academy of Management Perspectives, 30(3), 316-327.

Wenger, E., \& Snyder, W. (2000). Communities of practice: The organizational frontier. Harvard Business Review, 78(1), 139-146.

Wilkinson, R. G., \& Pickett, K. E. (2009). Income inequality and social dysfunction. Annual Review of Sociology, 35, 493-511.

Wilkinson, R., \& Pickett, K. (2017). Inequality and mental illness. The Lancet Psychiatry, 4(7), 512-513.

Winston, A. (2019). Is the Business Roundtable Statement Just Empty Rhetoric. Harvard Business Review, August 30. Retrieved December 3, 2021, from https://hbr.org/2019/08/is-the-business-round table-statement-just-empty-rhetoric.

Yunus, M., \& Weber, K. (2011). Building social business: The new kind of capitalism that serves humanity's most pressing needs. Public Affairs.

Publisher's Note Springer Nature remains neutral with regard to jurisdictional claims in published maps and institutional affiliations. 